\title{
The Polish-Chinese Economic Intensification in the Context of Legal Education: Selected Aspects
}

\begin{abstract}
The One Belt One Road initiative and overall intensification of Polish-Chinese trade relations need to be reflected in the field of legal education. For this reason, the paper compares the legal education systems in Poland and China, as well as it presents the main goals of the One Belt One Road project, summarizing the mutual business environments and describing the main challenges associated with them. The Authors also attempt to outline potential directions to be followed in legal education in the context of potential benefits to be derived from the initiative and propose possible solutions to achieve this aim.
\end{abstract}

Keywords:

Poland, China, One Belt One Road, legal education, law, trade relations

\section{INTRODUCTION}

The One Belt One Road is a contemporary initiative of the People's Republic of China authorities aimed at reactivating the formula of the Silk Road known for centuries. The New Silk Road concept is of interest to politicians, entrepreneurs

1 The INNOWACJA Scientific Circle, Faculty of Law, University of Białystok, Poland. E-MAIL: jakub.farhan@gmail.com ORCID: 0000-0002-3360-1553

2 Department of Public International Law, Faculty of Law, University of Białystok, Poland. E-MAIL: marcin_lukowski@outlook.com ORCID: 0000-0002-9819-6296

3 Department of Public International Law, Faculty of Law, University of Bialystok, Poland. E-MAIL: maper@post.pl ORCID: 0000-0002-3909-3967 
and researchers. The One Belt One Road's goal is strengthening connectivity and economic collaboration between China and countries in Asia, Europe and Africa by creating a land-based route (the belt) and a sea-based route (the road), linking China to Europe via countries across Eurasia and the Indian Ocean. The implementation of the designated goal will take place through a variety of infrastructural investments, such as the building of roadways, railways, maritime ports, power grids, oil and gas pipelines, and associated infrastructure projects (China's Belt and Road Initiative - Education, 2017). The Polish-Chinese relations are affected by this process. The accelerating economic cooperation between Poland and China, caused by the above, makes it necessary to take appropriate legal education activities in both countries. Since the end of the last century, there have been many scientific centers primarily focused on Chinese-Western legal education, such as the Paul Tsai China Center at Yale University, the Finnish China Law Center, and China-EU School of Law (CESL). It seems, however, that a project on such a scale as the One Belt One Road Initiative has implications in the area of preparation of future competent personnel familiar with Chinese and European law, which will enable harmonious cooperation within the new concept. It is necessary to adapt legal education in order to be able to take full advantage of the upcoming opportunities resulting from the initiative of this size.

From the Polish perspective, it is necessary to identify priorities and those areas in which legal education can contribute the most to the success of the New Silk Road initiative, on the one hand, and adequately safeguard the interests of the Republic of Poland, on the other hand. For this reason, this paper will compare the legal education systems in Poland and China and present the main assumptions of the One Belt One Road project, as well as the challenges associated with them. The authors will also attempt to outline possible solutions and indicate potential directions on which legal education should focus in the context of potential benefits of the New Silk Road initiative.

\section{THE NEW SILK ROAD AND OTHER MANIFESTATIONS OF THE POLISH-CHINESE ECONOMIC INTENSIFICATION}

The concept of the New Silk Road, as one of the programs of Chinese economic expansion, is part of the Middle Kingdom's trade policy being implemented for nearly 40 years. Its initiator was Xiaoping Deng, who opened the 12th Party Congress on September 1, 1982 in Beijing, stating: "We must combine the universal truth of Marxism with the specific Chinese reality and build socialism with Chi- 
nese character”. Today's reality, from the point of view of a state through which territory this route is to run, at first glance, the One Belt One Road concept may seem an extremely lucrative venture. Certainly, one must not forget about the long-term impact of this investment, inter alia, on its domestic economy, politics and broadly understood culture. It is unquestionable that with the development of the full volume of the New Silk Road, interdependent networks will immediately arise between states creating strong dependencies. On an unprecedented scale, this investment will open a new freight corridor increasing trade in EU-China relations.

Poland is a member state of the $16+1$ format, i.e., the group of 16 Central and Eastern European countries plus China (Kaczmarski \& Jakóbowski, 2015), within which the New Silk Road investment plans are discussed. Among the 16 European countries involved, there are 10 European Union members (the EU has an observer status in this group). However, Member States, including Poland, must be aware that their freedom to shape independently trade relations with China is limited by Treaties. The pursuit of customs policy is the exclusive competence of the EU. For this reason, Poland should conduct talks with China, but, at the same time, act within the EU and within the already existing legal order. EU-China relations are governed, for example, by the International Customs Co-operation and Mutual Administrative Assistance Agreements (International Customs Co-operation..., 2018), i.e., agreements forming the basis for cooperation between relevant customs administrations aiming at information exchange and counteracting fraud and illegal activities. Any unilateral actions by a Member State going beyond the powers conferred by the Treaty on European Union and the Treaty on the Functioning of the European Union may expose such a state to serious financial consequences. Within the EU (under the auspices of the World Customs Organization), Poland participates with China in a pilot trade program entitled Smart and Secure Trade Lanes Pilot (SSTL). The project participants benefit, inter alia, from simplified customs clearance.

However, it is not advisable to develop an excessive optimism, as Poland is not indispensable to China. In case of difficulties in implementing the land route within the Initiative, it is possible to focus on the maritime route, where the Chinese have already made significant investments. In turn, proceeding from the south, the Chinese have geopolitically secured access to the Suez Canal connecting the Indian Ocean and the Mediterranean Sea by building a military base in Djibouti. The state is located directly at the Mandeb Strait, which is a gateway to Europe that, hypothetically, can be easily closed by the Chinese. Another important point is one of the largest commercial seaports in Europe, i.e., the port of 
Piraeus, which is already owned by a Chinese company. Goods delivered from China to the port may be transported by rail via the Balkans. For this purpose, the Chinese decided to finance the connection between Serbia and Hungary. From there, further transport to Western Europe will be possible. However, China runs a multi-vector policy being interested not only in importing goods to Europe, but also in on-site production, not only in Eastern European countries. For example, the Volvo factory (which belongs to the Chinese car company Geely) will produce cars from the Chinese make Lynk in Ghent in Belgium. At the beginning of 2018, the Chinese company Worldwide Logistics Group took over the Polish logistic operator listed on the Warsaw Stock Exchange, ATC Cargo. It is supposed to make it easier to implement a huge investment of a Chinese company from the e-commerce industry. Alibaba, as this subject is referred to here, plan to build a logistic center at the western border of Poland, from which at the start the Polish, German and Czech markets will be supplied. The investment is clearly referred to as one of the elements of the New Silk Road initiative (Kaczmarczyk, 2018). Taking into account the five existing logistics centers in Poland, Alibaba's competitor - American Amazon, as well as the investment of German Zalando (Skrzat, 2018), it can be predicted that Poland has a chance to become an important actor in EastWest trade.

At present, it is difficult to accurately forecast the development prospects of the New Silk Road and other recently launched Polish-Chinese ventures. Probably they are progressive; therefore, the term "Polish - Chinese economic intensification” seems to be justified.

\section{LEGAL EDUCATION IN CHINA AND POLAND}

It should be pointed out that the current image of legal education in China is projected by the centuries-old tradition of feudalism, and due to the turbulent history of the 20th century, the tradition of rule of law and, consequently, legal education is very short. Therefore, it did not have time to fully develop and adapt to contemporary realities in China and in the international arena. In turn, Poland has the relevant centuries-old tradition (see: Kruszewski, 2011), although the Polish legal education system is similar to those that have developed in other European countries (Gostynski \& Garfield, 1993). Poland is a member state of the European Union and a party to the program known as the Bologna Process, which aims to increase the international competitiveness of the European higher education system, while at the same time unifying to a certain extent higher education in the 
Member States. Therefore, Polish legal education, as part of these considerations, may be treated in some matters more broadly - as an example of legal education in a European Union Member State. Legal studies in Poland, just as in entire Europe, are extremely popular. Graduating from legal studies is associated with prestige and the possibility of taking up an interesting lucrative job. In Poland, in the academic year 2017/2018, studies in law were at the 5th place in terms of the total number of candidates (Raport Ministerstwa Nauki i Szkolnictwa Wyższego o wynikach rekrutacji na rok akademicki 2017/2018, 2017). It seems that its important asset is the classic education formula, which is not the rule at the moment.

Poland's admission to the Bologna Declaration led to the establishment of the higher education system based on two main education cycles: first-cycle (BA/BSc) and second-cycle (MA/MSc). The field of law is offered as a unified, undivided, long-term Master's degree programme, with the possibility to continue studies at the third cycle ${ }^{4}$. It means that it lasts 5 years, excluding the possibility to obtain a bachelor's degree in law. After completing them and passing the diploma exam, within which the student is required to write a diploma thesis, and then answering questions related to the thesis before the committee, they obtain a Master's degree in law. They are therefore an exception to the two-cycle - in principle - form of studies.

The issue of the curriculum of studies is not unified within the European Union or even at the national level. In Poland, universities develop the curriculum of studies on their own based on a resolution of the faculty council. However, what is important, the indispensable basis common for all universities includes: jurisprudence, legal logic, constitutional law, criminal law, administrative law, civil law, administrative and court-administrative proceedings, criminal proceedings, civil proceedings, historical and legal subjects, and the necessity of (relatively short) professional practice. The subjects pursued at Polish law faculties are also: public international law, family and inheritance law, intellectual property law, European Union law, human rights, tax law, labor and social security law, political and legal doctrines, agricultural law, environmental law, foreign language classes ${ }^{5}$.

At law faculties, two basic teaching methods domineer. The first one is the lecture. It is based on an oral transmission of knowledge by a professor special-

$4 \S 17$ of the Regulation of the Minister of Science and Higher Education of September 26, 2016 Regarding the Conditions for Conducting Studies [Rozporzq̨dzenie Ministra Nauki i Szkolnictwa Wyższego z dnia 26 września 2016 r. w sprawie warunków prowadzenia studiów] (Journal of Laws of 2016, item 1596).

5 Reconstructed on the example of study curricula for law at the Maria Curie-Skłodowska University in Lublin, the University of Białystok, the University of Warsaw, and the Jagiellonian University. 
izing in a given branch of law. As a rule, it is characterized by low activation of students who remain rather passive, with the possibility of asking questions at the end of the lecture. They are of mass character since all students of a given year participate in them. The second method involves exercises and seminars. The exercises take place in smaller groups (usually 15 or 25 people). In this case, the teacher has a much greater opportunity to interact with students. In their course, more emphasis should be put on practical issues and the development of specific skills, not on theoretical knowledge. The seminar has a similar character to the exercises, but it is directed to more advanced students, usually at 4 th-5th grade of their studies, with specific knowledge on a given subject. In addition, it is run in smaller groups than exercises.

The most typical choice of a career path after graduation is the provision of legal services in such professions as attorney, legal counselor, notary public, patent attorney, or the public office functions: judge, prosecutor, court bailiff. Taking up the above-mentioned professions depends on completing the initial training (aplikacja), i.e., the practice of law graduates. It aims at deepening and updating legal knowledge; practical familiarization of trainees with the rules of performing professions and preparation for professional practice by, among others, performing tasks and practical exercises ordered by the patron and replacing him/her in professional activities; familiarizing the trainee with the rules of professional ethics; preparation for the vocational exam6. It is still a very popular path, despite the widespread opinion about saturation of the legal market. For example - according to the data published by the Ministry of Justice in 2017 - 7,997 people joined the entrance exams for the initial trainings for attorneys, legal counselors and court bailiffs (Wstępne wyniki egzaminów na aplikacje prawnicze, 2017).

It should be noted that not all graduates of law studies plan to complete the long-term and extremely demanding training. Some of them continue their education at doctoral studies, while others take up a job. They can find employment in government administration, local government units and private enterprises. In addition, extensive knowledge on law and soft competences acquired in the course of studies significantly facilitate starting own business, not necessarily strictly legal one.

6 Prepared on the basis of the regulations of the legal counselor's apprenticeship (resolution No. 20/X/2017 of the Presidium of the National Council of Legal Advisors of February 16, 2017), the regulations for attorneys' training (Announcement of the Presidium of the Supreme Bar Council of December 16, 2014 Regarding the Announcement of the Uniform Text of the Regulations for Serving a Lawyer's Apprenticeship) and the Regulation of the Minister of Justice of December 17, 2013, on the Organization and Course of the Notarial Training (Journal of Laws of 2013, item 1668). 
In turn, legal education in China has its specificity. Deng Xiaoping ended the Cultural Revolution and initiated the rule of law, following the model of European continental law. It was an event opening a new era in legal education. Recruitment for law departments began, and the number of applicants grew with a geometric progression. In 1977, after years of suspension of universities' activities during the Cultural Revolution, 256 students participated in the recruitment process, and a year later - 995. The statistics of 2014 show that 543,271 people applied for law studies (137,558 were admitted) (Wiedong, 2004, p. 2).

The issue of legal studies forms and professional qualifications in China is much more diverse than in Poland. Universities offer different types of courses - four-year, three-year and even two-year (see: Wang, 2002). It is assumed that the basic program is a four-year BA (Bachelors of Law), offered by law faculties at public universities (Ding, 2010, p. 113), and this most basic course of study will be the starting point of these considerations. The possibility to study is conditioned by the National Admission Test - a Chinese equivalent of the secondary schoolleaving examination (in Polish, matura), usually taken by students in the last year of high school (Ash, 2016).

The curriculum at law faculties is dependent on state bodies. The Steering Committee for legal education, created within the framework of the Ministry of Education, is to advise all law faculties on the issue of the curriculum and supervise their activities (Kong, 2009, p. 42). Most of the study programs begin with the principles of Marxist philosophy, the principles of Marxist economic policy, modern economics and world politics, national security, and military training. Additionally, classes in English and physical education are usually offered (Nielsen, 2011, p. 4). Since 1999, in each bachelor's program, the following subjects must be included: jurisprudence, constitutional law, history of law, criminal law, civil law, commercial law, criminal proceedings, civil proceedings, commercial law, administrative law, public international law, international private law, international commercial law, and criminology (Conner, 2009).

Chinese education is characterized by high level of theoretical attitude of the issues. It is based on compelling examinations testing the amount of memorized information rather than the skill of critical or creative thinking (see: Yuchtman, 2017). In the case of legal education the situation is similar. Knowledge transfer is primarily done in a passive way through lecturing - students only have to remember certain messages without having to acquire the ability to use them in practice. The basic formula of law teaching in China is to discuss the legal principles developed by the doctrine (in the domain of legal theory), legal rules, as well as memorizing codes and laws. Practical issues are rarely addressed, as well 
as real legal problems are rarely solved (Nielsen, 2011). This is one of the biggest problems of Chinese legal education. In theory, each student is required to undergo two or three-month internships in a law firm or in court offices. There is, however, no definite outline of the practices, which is why they boil down to a two- to threemonth break from usual activities (Phan, 2005, p. 127).

\section{PERSPECTIVES OF LEGAL EDUCATION IN THE CONDITIONS OF POLISH-CHINESE ECONOMIC INTENSIFICATION}

Initiatives regarding legal education courses should be complementary to the intensification of economic relations and strengthen bilateral relations between Poland and China. Only well-educated staff may influence the success of such a large undertaking. Since the educational process is time-consuming, appropriate tools contributing to future success must be implemented today.

Due to geographical location, in the case of land transport of goods from China, Poland will be the gateway to the European Union 500-million consumer market and Polish customs offices will be obliged to service customs. In most cases, it should be assumed that this would consist in carrying out the so-called special procedures within the meaning of Article 210 of the EU Customs Code, i.e.:

1) placing imported goods under the transit procedure to further move them into the EU customs territory, to other Member States,

2) placing goods under a special storage procedure, which includes placing goods in a customs warehouse,

3) to a lesser extent, the customs administration will deal with goods admission to trading in Poland.

Meanwhile, at most universities in Poland customs law is not included in the scope of the curriculum at all or is a subject of specialization. In practice, the method of obtaining the necessary knowledge in this field is mainly employment in the National Tax Administration (the former Customs Service). However, this solution is not perfect. Above all, efficiently moving around in the area of quite complicated issues of customs law requires gaining experience over years. Secondly, the number of available job positions is limited. Thirdly, due to low earnings in the public sector, the most talented individuals may not be interested in such a career model. As a result, the situation may occur where well-educated Chinese specialists (far exceeding Polish capabilities regarding their number) will be confronted with few Polish experts in the field of customs law. Despite the 
shortcomings of the Chinese education system and the emphasis on the theoretical model of teaching, the authorities of the Middle Kingdom have already taken steps to recruit cadres capable of implementing the New Silk Road project, as evidenced by the establishment of the China-EU School of Law (CESL). Moreover, the University of Shandong launched the International Projects Management program ${ }^{7}$ for students from the New Silk Road countries to get management staff in individual countries ready.

The implementation of the New Silk Road initiative will require a large number of specialists in alternative dispute resolution, i.e., people with knowledge on the subject of mediation and arbitration. The Chinese side seems to already notice the need. China plans to establish a Court of Arbitration in the ten-million city of Xi'an (China to Establish Court for OBOR Disputes, 2018), competent for disputes arising in connection with the implementation of the "one-lane and one-way" initiative. It can be assumed that the Chinese side, by signing agreements with European partners, will aim at making it the tribunal competent for resolving disputes. This means resigning from appealing to institutions with an established position such as the International Court of Arbitration ICC in Paris or the Arbitration Institute of the Stockholm Chamber of Commerce (in Stockholm). To ensure the impartiality of the Chinese tribunal, it is necessary to internationalize its composition in the future and, above all, to negotiate with China as to its final form now. These goals should be implemented at the government level, with the involvement of, inter alia, the Ministry of Foreign Affairs. However, one cannot forget about the role of the private legal services sector. In the event of a dispute with a Chinese entity, a representative of a Polish entrepreneur will turn to a well-known law firm and, in this way, they will usually seek assistance. The role of universities and legal professions self-governments is to properly prepare the professional communities of lawyers for new challenges.

It is a common Chinese practice to take over companies with an established position in local markets. When the right proportions are kept, there is nothing wrong with it, but the state (and the private sector) should possess tools to defend itself if the phenomenon takes on a mass character. This problem has recently appeared in Germany, where it was decided not to allow one of the German companies to be sold to the Chinese investor. Consequently, appropriate legal solutions should be sought at the national and EU level. It results in the need for appropriate training of specialists in the field of acquisition law, as well as antitrust law. While both areas are currently in the standard offer of the majority of medium and large

7 See: http://www.oboreurope.com/en/education-priority (accessed: 5.02.2018). 
law firms, the experience of lawyers so far mainly concerns acquisitions of Polish companies by entities from Western Europe or the United States. China is also not one of the largest foreign investors in Poland, which means that business experience with this partner is limited.

Experts with knowledge on China's practices in limiting access to the foreign market, including Polish and European investors, will be needed. Taking into account the rule of reciprocity governing international relations, relations with Chinese entrepreneurs should be accompanied by full awareness (from our perspective assessed negatively) of actions undertaken by the Chinese government to limit access to its market. Such knowledge can be an important bargaining chip if Chinese partners would accuse the European side of not complying with the rules. It is common practice in China to use local antitrust law to transfer its intellectual property to Chinese entities by foreign companies. Therefore, legal education should focus not only on the theoretical aspect, but also on the practical one. Universities, as well as government and local government institutions, using their extensive relations, should as far as possible facilitate Polish students and specialists to practice in Chinese companies and administration bodies. Mobility of students within, inter alia, the Erasmus+ program, also open to third-country nationals (non-EU citizens), is an initiative that has a significant impact on the integration of participating states. It allows for education of students and young entrepreneurs and specialists aware of the opportunities offered by international cooperation, significantly broadening their horizons. It seems that a reasonable solution is to expand existing student exchange programs for more intensive exchanges between Poland and China, or to create a new similar program dedicated exclusively to these exchanges. On the Polish side, students participating in such initiatives would have a greater awareness of the specificity of culture and Chinese law, while Chinese students would learn about European law and customs. This is also particularly important due to the strong language barrier - the Chinese language is constructed in a completely different way from European languages, so learning English is much more difficult for a student from China than it is in a case of a Polish student.

The Polish-Chinese economic intensification is also a challenge for the regional administration. For example, the Podlaskie Voivodeship should take actions aimed at ensuring the inflow of specialized personnel educated in terms of knowledge of customs law. To this end, the Faculty of Law of the University of Bialłystok could sign a framework agreement on cooperation with the Chamber of Fiscal Administration in Białystok and introduce the subjects of "customs law" and "international commercial law" to the study curriculum. Cooperation of the 
University of Białystok with the Białystok University of Technology (BUT) within the operation scope of the International Chinese and Central-Eastern European Institute of Logistics and Service Sciences jointly established by the BUT and the Chinese university (the Zhejiang University Ningbo Institute of Technology) is also worth considering. The suggested activities are aimed at educating experts and creating a knowledge base on European and Chinese customs and commercial law, in order to broaden legal knowledge in the societies of both partners. Starting such activities at an early stage will allow to identify the biggest discrepancies and propose ways to reduce them. Thanks to this, when discussions on specific investments start, legal issues will not hinder negotiations, but simply the opposite, i.e., having secured their content, they will encourage parties to efficient decisionmaking.

The processes presented in the paper have already begun. The dynamics of the business environment are - so far - much faster than the accommodative possibilities of the legal education systems. Due to it, optimization concepts in the interdisciplinary formula (pedagogy, cultural studies, sociology, history, political science, etc.) are worth discussing.

\section{References}

Announcement of the Presidium of the Supreme Bar Council of December 16, 2014 Regarding the Announcement of the Uniform Text of the Regulations for Serving a Lawyer's Apprenticeship.

Conner, A.W. (2009). China's Lawyers and Their Training: Enduring Influences and Disconnects. In: J. Gillespie, \& A.H.Y. Chen (Eds.), Legal Development in East Asia: China and Vietnam Compared (pp. 276-298). London: Routledge.

Ding, X. (2010). The Reform of Legal Education in China and Japan: Shifting from the Continental to the American Model. Journal of Civil Law Studies, 3(1), pp. 111-129.

Gostynski, Z., \& Garfield, A. (1993). Taking the Other Road: Polish Legal Education During the Past Thirty Years. Temple International \& Comparative Law Journal, 7(2), pp. 243-286.

Kong, Q. (2009). Practice in Legal Education: International Experience and Chinese Response. Pacific McGeorge Global Business \& Development Law Journal, 22, pp. 35-44.

Kruszewski, T. (Ed.) (2011). Nauka i nauczanie prawa w dziejach. Wrocław: Kolonia Limited.

Nielsen, N. (2011). Legal Education in China: How do Chinese Universities Prepare Law Students for Legal Practice. Retrieved from: http://www.academia.edu/3643300/Legal_ education_in_China_How_do_Chinese_universities_prepare_law_students_for_legal_ practice.

Phan, P.H. (2005). Clinical Legal Education in China: In Pursuit of a Culture of Law and a Mission of Social Justice. Yale Human Rights and Development Journal, 8(1), pp. 117-152. 
Regulation of the Minister of Justice of December 17, 2013, on the Organization and Course of the Notarial Training (Journal of Laws of 2013, item 1668).

Resolution No. 20/X /2017 of the Presidium of the National Council of Legal Advisors of February 16, 2017.

Rozporządzenie Ministra Nauki i Szkolnictwa Wyższego z dnia 26 września 2016 r. w sprawie warunków prowadzenia studiów. (Journal of Laws of 2016, item 1596).

Wang, Z. (2002). Legal Education in Contemporary China. The International Lawyer, 36(4), pp. 1203-1212.

Wiedong, J. (2004). Legal Education in China: a Great Leap Forward of Professionalism. Kobe University Law Review, 39, pp. 1-21.

Yuchtman, N. (2017). Teaching to the Tests: An Economic Analysis of Traditional and Modern Education in Late Imperial and Republican China. Explorations in Economic History, 63, pp. 70-90. DOI: 10.1016/j.eeh.2016.11.003.

\section{Online resources}

Ash, A. (2016). Is China's Gaokao the World's Toughest School Exam? The Guardian. Retrieved from: www.theguardian.com/world/2016/oct/12/gaokao-china-toughest-school-examin-world (accessed: November 1, 2017).

China-EU School of Law. Retrieved from: http://en.cesl.edu.cn/About_us.htm (accessed: October 20, 2017).

China's Belt and Road Initiative - Education, 27.11.2017. Retrieved from: https://internationaleducation.gov.au/International-network/china/PolicyUpdates-China/Pages/Chinas-Beltand-Road-Initiative-.aspx (accessed: November 16, 2018).

China to Establish Court for OBOR Disputes. Asia Times, 25.01.2018. Retrieved from: http:// www.atimes.com/article/china-establish-court-obor-disputes (accessed: February 5, 2018).

Finnish China Law Center. Retrieved from: http://blogs.helsinki.fi/chinalawcenter/objectives (accessed: October 20, 2017).

International Customs Co-operation and Mutual Administrative Assistance Agreements. (2018). Retrieved from: https:/ec.europa.eu/taxation_customs/business/international-affairs/ international-customs-cooperation-mutual-administrative-assistance-agreements_en (accessed: February 5, 2018).

Kaczmarczyk, M. (2018). Czas rekordów na polskim rynku magazynowym. Newsweek, 26.03.2018. Retrieved from: http://m.newsweek.pl/biznes/rozwoj-polskiego-rynkumagazynowego-i-wplyw-e-commerce,artykuly,425068,1.html (accessed: November 16, 2018).

Kaczmarski,M.,\&Jakóbowski,J.(2015).Chiny-EuropaŚrodkowo-Wschodnia:„16+1”widziane z Pekinu. Komentarze OSW, 166. Retrieved from: https://www.osw.waw.pl/sites/defa ult/files/komentarze_166.pdf (accessed: February 4, 2017).

Raport Ministerstwa Nauki i Szkolnictwa Wyższego o wynikach rekrutacji na rok akademicki 2017/2018 [Report of the Ministry of Science and Higher Education on the Results of Recruitment for the Academic Year 2017/2018], 29.11.2017. Retrieved from: http://www. nauka.gov.pl/aktualnosci-ministerstwo/znamy-wyniki-rekrutacji-na-studia-w-roku2017-18.html (accessed: March 18, 2018). 
Skrzat, P. (2018). Olbrzymia inwestycja Chińczyków w Polsce. Właściciel AliExpress stawia centrum logistyczne. Money.pl, 23.02.2018. Retrieved from: https://www.money.pl/gospodarka/wiadomosci/artykul/aliexpress-alibaba-centrum-logistyczne,26,0,2401562. html (accessed: March 18, 2018).

Wstępne wyniki egzaminów na aplikacje prawnicze, 2.10.2017. Retrieved from: www.ms.gov. pl/pl/informacje/news,9815,wstepne-wyniki-egzaminow-na-aplikacje-prawnicze.html (accessed: October 20, 2017).

Yale Law School (2017). Retrieved from: https://law.yale.edu/china-center/programs/chineselegal-reform (accessed: October 20, 2017). 